\title{
Genotoxic effect of Catha edulis (khat) crude extract after sub-chronic administration in rats.
}

\begin{abstract}
The aim of this study was to evaluate the genotoxic effects of a crude extract of khat (Catha edulis, Forsk) leaves in rats. Two groups were fed khat crude extract, 1000 and $2000 \mathrm{mg} / \mathrm{kg}$ body weight, for 90 days and were compared with a control group. The alkaline $(\mathrm{pH}>13$ ) version of comet assay was used in this study. However, no previous published work has been undertaken and showed the effect of khat on DNA migration in the comet assay. To compare the comet assay results with another genetic endpoint, blood samples were analyzed for chromosomal aberrations. These results showed no DNA damage detected using comet assay in both the khat treated groups, while the results of chromosomal aberrations assay showed a significant increase $(\mathrm{P}<0.05)$ in the $2000 \mathrm{mg} / \mathrm{kg}$ body weight treated group compared to the control group.
\end{abstract}

Keyword: Catha edulis; Chromosome aberration assay; Comet assay; Genotoxicity; Khat. 